\title{
Understanding U.S. Cross-Border Securities Data
}

Carol C. Bertaut, William L. Griever, and Ralph W. Tryon, of the Board's Division of International Finance, prepared this article. Stephen S. Gardner and Jonas J. Robison provided research assistance.

In recent years, foreign holdings of U.S. securities have grown markedly. During 2005, reported foreign holdings increased nearly $\$ 1$ trillion for the second consecutive year, bringing the estimated total to about $\$ 7.3$ trillion, or roughly 16 percent of all U.S. longterm securities outstanding at year-end. These large numbers are understandably attracting a great deal of attention, as external deficits are a subject of growing concern in today's global economy.

In this article, we present current data on U.S. cross-border securities holdings and transactions and describe the system that collects the data. We discuss how to make the best use of the information available by avoiding common misinterpretations of the data and by adjusting the published figures to improve their accuracy and comprehensiveness. We also discuss how to construct monthly estimates of crossborder securities holdings by country, combining monthly transactions data with less frequently reported positions data. Besides providing moretimely measures of holdings of securities, these estimates incorporate a number of adjustments that improve our overall picture of cross-border portfolio positions. Finally, to improve our ability to correctly attribute U.S. liabilities to foreign holders, we compare our estimates of foreign holdings of U.S. securities with estimates obtained from asset surveys conducted by other countries.

\section{INCREASING IMPORTANCE OF FOREIGN HOLDINGS OF U.S. SECURITIES}

The increasing importance of foreign holdings of U.S. securities can be seen by comparing the growth of these holdings with the growth of U.S. ownership of foreign securities. Since 1994, when the first survey of U.S. holdings of foreign long-term securities was conducted, foreign ownership of U.S. long-term securities has consistently exceeded U.S. ownership of foreign long-term securities. At the end of 1994, the market value of foreign holdings was approxi- mately 40 percent higher than that of U.S. holdings; by the end of 2005 , it was approximately 70 percent higher. The more-rapid growth of foreign holdings of U.S. securities over the past ten years is the counterpart to the record U.S. trade and current account deficits incurred over the period, as the financial inflows associated with the deficits have occurred largely through foreign purchases of U.S. securities.

The trend in foreign holdings relative to U.S. holdings varies by type of security. In recent years, U.S. holdings of foreign equity have been somewhat larger than foreign holdings of U.S. equity (figure 1). For holdings of long-term debt, however, the situation has been very different, as foreign holdings have exceeded U.S. holdings by a wide margin. The disparity can be partly explained by the holdings of foreign official institutions, which are discussed in detail later in this article.

An increase in the level of foreign holdings of U.S. securities has also resulted in an increase in the share of U.S. securities that are foreign held. Since 1974, when surveys began to collect data on foreign ownership of U.S. long-term securities, the share of the total value of U.S. long-term securities held by foreigners has more than tripled, from less than 5 percent to 16 percent as of June 2005 (table 1). As a fraction of

1. Foreign holdings of U.S. long-term securities and U.S. holdings of foreign long-term securities, by type of security, 1994-2005

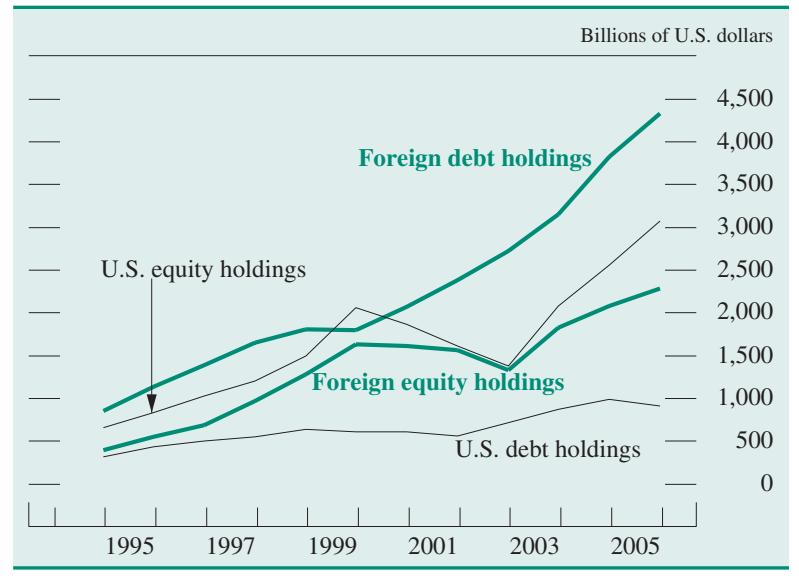

SourCE: Treasury International Capital reporting system and staff estimates. 
1. Foreign holdings of U.S. long-term securities as a share of such securities outstanding, by type of security and for survey dates, 1974-2005

Percent

\begin{tabular}{|c|c|c|c|c|c|}
\hline \multirow{3}{*}{$\begin{array}{l}\text { Month } \\
\text { and } \\
\text { year }\end{array}$} & \multicolumn{5}{|c|}{ Type of security } \\
\hline & \multirow[b]{2}{*}{ All } & \multirow[b]{2}{*}{ Equity ${ }^{1}$} & \multicolumn{3}{|c|}{ Debt } \\
\hline & & & $\begin{array}{c}\text { U.S. } \\
\text { Treasury }{ }^{2}\end{array}$ & $\begin{array}{l}\text { U.S. } \\
\text { govern- } \\
\text { ment } \\
\text { agency }\end{array}$ & Other ${ }^{3}$ \\
\hline Dec. 1974 & 5 & 4 & 15 & n.a. & n.a. \\
\hline Dec. 1978 & 4 & 5 & 12 & 3 & 1 \\
\hline Dec. 1984 & 6 & 5 & 14 & 3 & 3 \\
\hline Dec. 1989 & 9 & 6 & 22 & 4 & 7 \\
\hline Dec. 1994 & 8 & 5 & 19 & 5 & 8 \\
\hline Mar. 2000 & 10 & 7 & 35 & 7 & 12 \\
\hline June 2002 & 12 & 8 & 41 & 10 & 16 \\
\hline June 2003 & 14 & 9 & 46 & 11 & 16 \\
\hline June 2004 & 14 & 9 & 52 & 11 & 17 \\
\hline June 2005 & 16 & 10 & 52 & 14 & 20 \\
\hline
\end{tabular}

NOTE: Percentages should be viewed as approximate, as data on the total value of U.S. long-term securities outstanding by security type are unavailable on the same basis as that used in collecting the survey data on foreign holdings of such securities. For example, whereas data on total U.S. long-term debt securities outstanding are based on the face value of the securities, data on foreign holdings are based on their market value. However, the percentages should still be useful for showing long-term trends.

1. Both common and preferred stock as well as all types of investment company shares, such as open-end, closed-end, and money market mutual funds.

2. Marketable Treasury securities only.

3. U.S. debt securities issued by all other institutions, primarily corporate issuers.

n.a. Not available.

SourCE: U.S. Department of the Treasury, Report on Foreign Portfolio Holdings of U.S. Securities, various dates.

the total outstanding, holdings are greatest in Treasuries: More than half of all marketable Treasury securities held by the public are foreign owned. In terms of market value, the level of foreign holdings of U.S. long-term securities increased from $\$ 67$ billion as of year-end 1974 to $\$ 6.3$ trillion as of June 2005.

2. Total foreign and foreign private holdings of U.S. short-term debt securities, and total U.S. holdings of foreign short-term debt securities, 1994-2005

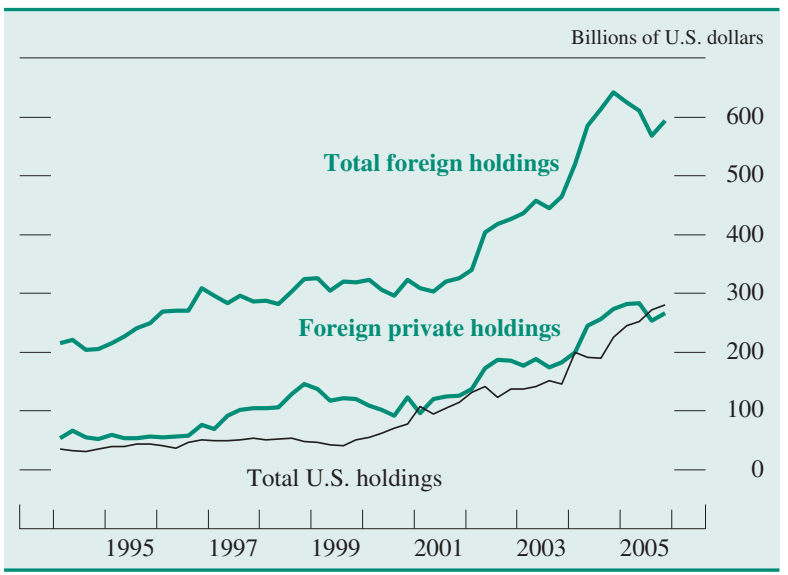

SouRCE: Treasury International Capital reporting system.
3. Total foreign holdings and foreign official holdings of U.S. short-term Treasury securities, 1994-2005

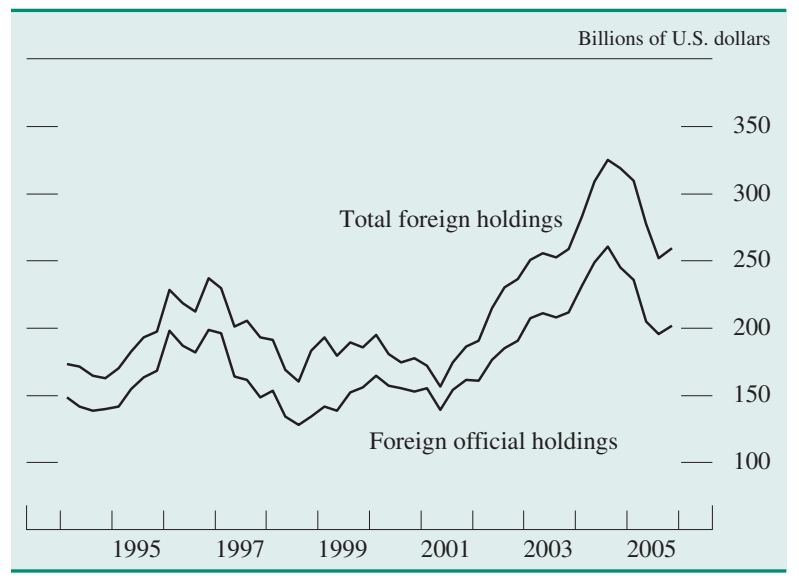

SouRCE: Treasury International Capital reporting system.

A similar relationship holds for relative sizes of foreign and U.S. holdings of short-term securities, although the magnitude of these holdings is considerably smaller. Total foreign holdings of U.S. shortterm debt securities are more than twice as large as U.S. holdings of foreign short-term debt securities, in large part because of the sizable holdings of foreign official institutions (figure 2). The importance of holdings by foreign official institutions is especially striking for short-term Treasury securities (figure 3). As shown in the figure, foreign official holdings account for more than three-fourths of short-term Treasury securities held by foreigners.

\section{THE TIC REPORTING SYSTEM}

The data that underlie these estimates of U.S. crossborder financial activity are collected by the Treasury International Capital (TIC) reporting system. ${ }^{1}$ This system is more comprehensive than many users realize. Users often assume that the TIC system collects only monthly data on cross-border transactions in long-term securities. Although these data receive considerable attention in the financial press, they constitute only a small part of the TIC system.

Besides the transactions data, which cover only long-term securities (that is, securities with an original maturity of more than one year), the TIC system includes monthly and quarterly cross-border data (including holdings of short-term securities) reported

1. TIC data are published on the Treasury Department's website at www.treas.gov/tic/. The website includes past and present data, articles about the TIC system, TIC forms and instructions, related non-TIC websites, and TIC contact information. 
by banks and broker-dealers; periodic (now annual) in-depth surveys of cross-border holdings of both long- and short-term securities; and quarterly position data reported by nonbank respondents such as commercial concerns, exporters and importers, and other financial institutions. In 2005, the TIC system also began to collect data on cross-border derivatives positions. $^{2}$

\section{Transactions in Long-Term Securities}

Information on cross-border transactions in U.S. and foreign long-term securities is collected monthly on the TIC S form. Data are collected by country, at market value, and are published with a forty-five-day lag. The primary respondents for these transactions data are U.S.-resident brokers and dealers, although some end investors and security issuers also report on the TIC S.

For U.S. securities, data are collected separately for four types of securities: equity, U.S. Treasury debt, U.S. government agency debt, and debt issued by all other institutions (primarily corporate issuers). For foreign securities, only two security types, equity and long-term debt, are separately measured. Information on foreign official purchases of U.S. securities is also collected separately from information on purchases by other foreigners.

For analytical purposes, the sales of each type of security are usually subtracted from gross purchases to measure net transactions. The $\mathrm{S}$ form follows international reporting conventions for measuring the balance of payments: It reports foreign net purchases of U.S. long-term securities with a positive sign because they are a source of capital inflow to the United States, and it reports U.S. net purchases of foreign long-term securities with a negative sign because they are a source of capital outflow from the United States. ${ }^{3}$

2. For all monthly and quarterly TIC forms, reporting is required by law as long as the reporter has cross-border activity above the exemption level set for that form.

3. The TIC S form reports all data from the perspective of the foreign resident involved in the cross-border transaction. Thus, when a U.S. investor purchases a foreign security, the transaction is reported as a foreign sale of a foreign security. Likewise, when a U.S. investor sells a foreign security, the transaction is recorded as a foreign purchase of a foreign security. Therefore, net foreign sales of foreign securities are equivalent to net U.S. purchases of foreign securities. The data on transactions in foreign securities are also reported in this way in the TIC system's online files of gross purchases and gross sales.

\section{Holdings of Short-Term Securities}

Selected data on cross-border holdings of short-term securities are collected monthly or quarterly, but these data may be less well known than the data on transactions in long-term securities because they are reported and released with the banking data collected on the TIC B forms. The B data include foreign holdings of U.S. short-term securities-such as U.S. Treasury bills and certificates, U.S. government agency securities, commercial paper, and negotiable certificates of deposit (collected in the banking liabilities data) as well as U.S. holdings of similar types of foreign short-term securities (collected in the banking claims data). The primary respondents for these position data are U.S.-resident custodians that report their holdings on behalf of their customers.

Like the $\mathrm{S}$ data on long-term securities transactions, the B data on short-term securities holdings are collected by country and by broad class of security type, such as U.S. Treasury securities; these data are also reported by major foreign counterparties, including foreign official institutions, foreign banks, and other private foreigners. The short-term securities data are reported at face value; data on U.S.-dollardenominated and foreign-currency-denominated securities are reported separately. Because the shortterm securities data are reported as positions, net transactions in these securities must be calculated as the change in position from one period to another. The $\mathrm{S}$ forms and the $\mathrm{B}$ forms provide much less detail than do the periodic surveys, which are discussed in the next section. Nevertheless, because the data are released about forty-five days after the end of a given month, they offer a timely and fairly comprehensive measure of cross-border securities flows.

\section{Annual Surveys of Holdings of Long- and Short-Term Securities}

More-comprehensive data on the level of both foreign holdings of U.S. securities (U.S. liabilities) and U.S. holdings of foreign securities (U.S. assets) are measured in the annual surveys. As noted earlier, the surveys now collect data on both long- and shortterm securities. ${ }^{4}$ Whereas in other parts of the TIC system the respondents report data in aggregate by country and by broad instrument type, respondents to

4. The annual surveys collected data on only long-term securities until the December 2001 survey of U.S. holdings of foreign securities. Data on foreign holdings of U.S. short-term securities were first collected in the June 2002 survey. 
the surveys report information on cross-border holdings on a security-by-security basis.

Collecting data on holdings of individual securities allows for much more detailed data reporting and significantly improves survey accuracy, but it also requires the processing of a large number of records (more than 500,000 for the asset surveys and almost 2.8 million for the liabilities surveys). The surveys thus take much longer to complete than do other reports for the TIC system: Preliminary results are usually available after nine months and final data after twelve months. However, the greater detail in the data collected permits the surveys to produce information that is otherwise unavailable, such as currency composition, maturity structure, industry sector, both face and market value of holdings, and the specific securities held. Liabilities surveys measure positions as of June 30, and asset surveys measure them as of December 31.5

\section{Banking and Nonfinancial Corporate Data}

Besides data on holdings of short-term securities, the B forms collect data on cross-border positions in the form of deposits, loans, brokerage balances, and repurchase agreements. Although these data are commonly referred to as the TIC "banking" data, they include positions reported by entities other than banks, such as other depository institutions, bank and financial holding companies, and securities brokers and dealers.

Cross-border positions of "nonbanks" (including entities such as exporters and importers, industrial firms, insurance companies, and pension funds) are collected quarterly, by country, on the TIC C forms. The $\mathrm{C}$ forms distinguish between "financial" claims and liabilities (such as deposits, short-term securities, and loans) and "commercial" claims and liabilities (such as accounts receivable or payable arising from import or export activities). Compared with the data reported on the $\mathrm{B}$ forms, the $\mathrm{C}$ data report much smaller cross-border positions. As of year-end 2004, total bank-reported claims and liabilities (excluding short-term securities) were about $\$ 2$ trillion and $\$ 2.4$ trillion respectively. In contrast, the corresponding amounts for nonbanks were only about $\$ 200$ billion and $\$ 100$ billion. In part, these smaller reported positions illustrate the difficulty of collecting accu-

5. The dates of the surveys are staggered primarily to reduce the year-end reporting burden on the institutions that report the survey data. rate cross-border data from a diverse and evolving set of participants. ${ }^{6}$

\section{USE OF TIC DATA IN THE BALANCE OF PAYMENTS AND FLOW OF FUNDS ACCOUNTS}

The most comprehensive measures of cross-border financial flows and positions are those that the Bureau of Economic Analysis (BEA) reports in the quarterly balance of payments accounts and in the annual net international investment position. ${ }^{7}$ The portfolio statistics in these international accounts are based on the monthly and quarterly TIC securities data and on the annual surveys. However, the balance of payments accounts also include flows and positions calculated from the remaining TIC bank- and nonbank-reported data, as well as information on direct investment collected and compiled by the BEA.

The TIC data are also used as inputs in the estimates for the "rest of the world" sector, included in the flow of funds accounts compiled by the Board of Governors of the Federal Reserve System. In most estimates of financial flows and holdings for that sector, the flow of funds accounts incorporate the BEA's official balance of payments statistics, and thus the flow of funds statistics are based only indirectly on the TIC data. However, if the balance of payments statistics are not yet available, the estimates for the rest of the world in the preliminary release of the flow of funds accounts for a given quarter are derived directly from the TIC data. ${ }^{8}$

\section{ISSUES IN THE COLLECTION AND INTERPRETATION OF THE TIC SECURITIES DATA}

While recognizing that the TIC system covers a variety of cross-border financial transactions, we will focus in the remainder of this article on interpreting the TIC data on securities - that is, the monthly trans-

6. This problem affects cross-border data collection not only in the United States but also in other countries. For example, an International Monetary Fund conference on capital flow and debt statistics pointed to a general difficulty in obtaining accurate and timely information on the cross-border activity of nonbank commercial concerns. Refer to the conference summary, note 13, at www.imf.org/external/ pubs/ft/seminar/2000/capflows/summary.htm.

7. The BEA's data on international accounts, including the balance of payments accounts and the international investment position, are published in the Survey of Current Business and at the BEA's website (www.bea.gov/bea/di1.htm).

8. The flow of funds accounts are published at www.federalreserve.gov/releases/z1/current/default.htm. 
actions data on long-term securities, the monthly position data on short-term securities, and the annual survey data. The following sections discuss topics related to the design and accuracy of the TIC system that should be understood for proper interpretation of these data. But because cross-border financial inflows can come through various means, including through the banking system and through direct investment, it is important to view the cross-border securities data in this broader context.

\section{Country Attribution}

The collection of accurate country-level data on cross-border financial activity ranges from straightforward to virtually impossible, depending on the type of data to be collected and the method of collection.

The country attribution of the portfolio asset surveys should be extremely accurate. The annual position surveys, by design, attempt to collect information by country of issuer for foreign securities and by country of foreign owner for U.S. securities. And because the surveys collect data at the level of individual securities, precisely identifying each security issuer's country of residence-from information supplied by survey reporters as well as from commercial data sources-is a relatively straightforward task.

In the liabilities surveys, however, the involvement of chains of intermediaries in the custody or management of securities frequently makes accurate identification of the actual owners of U.S. securities impossible. For example, a resident of Italy may buy a U.S. security and entrust it to a custodian bank in Switzerland. The Swiss bank, in turn, will typically employ the services of a U.S.-resident custodian to facilitate settlement and custody operations. When surveys are conducted, information is collected only from U.S.resident entities. Thus, the U.S.-resident bank, acting as the subcustodian of the Swiss bank, will report this security on the survey. Because the U.S. bank will typically know only that it is holding the security on behalf of a Swiss bank, it will report the security as Swiss held. This practice tends to create a "custodial bias" in the liabilities surveys by attributing excessively large holdings to countries that are major custodial, investment management, or security depository centers, such as Belgium, the Cayman Islands, Luxembourg, and Switzerland. An additional problem is caused by bearer, or unregistered, securities. Because no information is typically available on the ownership of these securities, they are listed on the surveys as "country unknown." In the June 2005 survey, foreign holdings attributed to that category amounted to almost $\$ 200$ billion.

Another problem of country attribution occurs in the reporting of monthly transactions data. The monthly transactions data, by design, record purchases and sales against the country from which transactions are made, which is not necessarily the country of the ultimate purchaser or actual seller (in the case of foreign transactions in U.S. securities) or the country of issuance (in the case of U.S. transactions in foreign securities). This reporting convention means that if, for example, a resident of Germany buys a U.S. Treasury bond and the transaction is booked through a London broker, the TIC S data will show a net purchase of a Treasury bond recorded against the United Kingdom, not Germany. Likewise, if a U.S. investor purchases French equity from a dealer in Switzerland, the TIC S data will report a U.S. net purchase of foreign equity from Switzerland. As transactions tend to be concentrated in major international financial centers, such as the United Kingdom and the Cayman Islands, the monthly data show a significant financial center "transactions bias" that often gives an inaccurate picture of the nationality of the actual foreign buyers and sellers.

\section{Foreign Official Institutions}

Data on foreign ownership of U.S. securities are divided into holdings of foreign official institutions and holdings of foreign private investors. Contrary to the assumptions of many data users, the holdings of foreign official institutions as reported in the TIC system consist of more than the foreign reserve asset holdings of central banks and of other foreign government institutions involved in the formulation of international monetary policy. They also include the holdings of foreign government-sponsored investment funds and other foreign government institutions, and thus they may differ from data on reserve asset holdings found elsewhere.

The distinction between foreign official and other foreign investors is made because the motivations of official investors for holding U.S. securities may differ from those of private investors. The rapid buildup in U.S. liabilities since 2001 is due in part to the substantial acquisition by foreign official institutions of U.S. long-term securities, especially long-term U.S. Treasury and U.S. government agency securities. By year-end 2005, foreign official institutions are estimated to have held approximately $\$ 1.8$ trillion of the total $\$ 6.7$ trillion in U.S. long-term securities held by all foreign investors (figure 4). 
4. Total foreign, foreign private, and foreign official holdings of U.S. long-term securities, 1994-2005

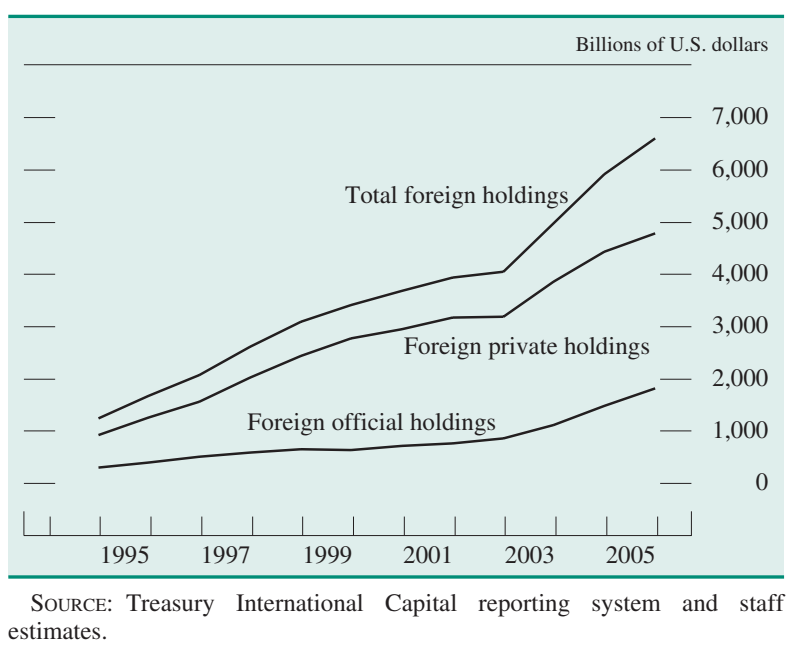

Accurately distinguishing official from private holders, however, is difficult for the same reasons that obtaining accurate information on the country of foreign owners of U.S. securities is difficult. Chains of intermediaries can obscure not only the country but also the type of foreign holder. Thus, foreign official holdings are almost certainly undercounted in the TIC data, though the degree of undercount is less in the annual surveys than in the monthly transactions data. The undercount in the transactions data is evident when the results of a new annual survey become available: Frequently, measured official holdings in the new survey exceed those derived from summing the monthly transactions since the previous survey (table 2).

To understand how foreign official acquisitions of U.S. securities may be undercounted, consider the following example. Suppose a foreign official institution acquires a U.S. security, such as a U.S. Treasury bond, from a private foreign entity on a foreign securities exchange and then has the security moved to the United States to be held in custody at the Federal Reserve Bank of New York. In this case, the surveys will report increased holdings of Treasury securities by foreign official institutions, but no corresponding foreign official purchase will be recorded on the TIC $S$ because the acquisition by the foreign official institution from another foreigner is not a U.S. cross-border transaction; rather, it is a foreign-toforeign transaction. Note, however, that when the private foreigner first acquired the Treasury security, a U.S. cross-border transaction should have been reported in the TIC system. But it would not have been recorded as a foreign official purchase, nor would it necessarily have been recorded in the same
2. Market value of foreign official holdings of U.S. long-term Treasury bonds: Comparison of survey results with estimated values, for survey dates, 2000-05 Billions of dollars

\begin{tabular}{|c|c|c|}
\hline Month and year & Survey ${ }^{1}$ & Estimate $^{2}$ \\
\hline Mar. 2000 & 492 & 436 \\
\hline June 2002 & 561 & 454 \\
\hline June 2003 & 653 & 605 \\
\hline June 2004 & 923 & 846 \\
\hline June 2005 & 1,073 & 1,028 \\
\hline
\end{tabular}

NoTE: Foreign official holdings consist of foreign reserve asset holdings, holdings of foreign government-sponsored investment funds, and holdings of foreign government institutions not involved in the formulation of international monetary policy.

1. Surveys of foreign holdings of U.S. securities (liabilities).

2. Result of adding monthly transactions at market value to the market value amounts measured by the most recent survey.

SOURCE: For survey results (except for June 2005), U.S. Department of the Treasury (2004), Report on Foreign Portfolio Holdings of U.S. Securities, June 30; result for June 2005 is from the preliminary release of the 2005 survey of foreign portfolio holdings of U.S. securities. For estimated values, Treasury International Capital reporting system, "Major Foreign Holders of Treasury Securities" (table), www.treas.gov/tic/mfh.txt.

calendar month or against the same country as was the movement into U.S. custody. ${ }^{9}$

\section{Effects of Exchange Rate Changes and Other Valuation Adjustments}

Although many users of the TIC data assume that foreign securities held by U.S. investors are exclusively denominated in foreign currencies and that U.S. securities held by foreign investors are exclusively denominated in U.S. dollars, such is not the case. According to the most recent data available (for 2004), 74 percent of the $\$ 1.2$ trillion in U.S. holdings of foreign debt securities were denominated in U.S. dollars, whereas 12 percent of the $\$ 4.1$ trillion in foreign holdings of U.S. debt securities were denominated in foreign currencies. ${ }^{10}$

Accounting correctly for the currency denominations of U.S. holdings of foreign securities and of foreign holdings of U.S. securities allows for moreaccurate measurement of valuation changes resulting from exchange rate fluctuations. In any given year, the effects of such fluctuations can be larger than total net securities flows during the year. For example, given the level of cross-border holdings of both

9. For more information, including a comparison of TIC data on foreign official holdings of Treasury and agency securities with Federal Reserve data on such securities held in custody at the Federal Reserve Bank of New York for official accounts, refer to "Frequently Asked Questions (FAQs) regarding the TIC System and TIC data," FAQ 10, www.treas.gov/tic/faq1.html.

10. For the currency denominations of U.S. holdings of foreign securities, refer to www.treas.gov/tic/shc2004r.pdf, p. 11; for the currency denominations of foreign holdings of U.S. securities, refer to www.treas.gov/tic/shl2004r.pdf, p. 117. 
equity and debt securities at the end of 2004, a 10 percent appreciation in the value of the U.S. dollar would have resulted in a net loss of $\$ 250$ billion to the U.S. balance sheet, as it would have decreased the value of U.S. holdings of foreign securities (U.S. assets) denominated in foreign currencies approximately $\$ 300$ billion while decreasing the value of foreign holdings of U.S. securities (U.S. liabilities) only about $\$ 50$ billion (because most U.S. securities are U.S.-dollar-denominated and thus unaffected). ${ }^{11}$ Other asset price changes, such as changes in the value of U.S. or foreign equities, can also have sizable effects on the value of securities holdings.

\section{Asset-Backed and Zero-Coupon Securities}

When estimating the value of cross-border securities holdings, analysts should take into account more than the measured levels of holdings, the measured levels of transactions, and fluctuations in prices and exchange rates. The reason is that some securitiesnamely, asset-backed and zero-coupon securitiesgain or lose value over time even if there are no cross-border transactions and prices and exchange rates remain stable.

Because many asset-backed securities repay principal on a regular basis, they decrease in value over time. These principal repayment flows are not recorded by the TIC S monthly transactions system, but the effects of these principal repayments on the value of asset-backed holdings are measured by the annual position surveys. Asset-backed securities account for a growing share of foreign holdings of U.S. government agency debt and U.S. corporate debt: As of June 30, 2002, asset-backed securities represented 25 percent of foreign holdings of U.S. agency securities and 15 percent of foreign holdings of corporate debt securities. By June 30, 2005, these proportions had increased to 33 percent and 26 per-

11. The effect of a 10 percent appreciation in the U.S. dollar will be perceived differently depending on whether these holdings are viewed as U.S. liabilities (the U.S. perspective) or as foreign assets (the foreign perspective). For example, assume that foreign residents own $\$ 100$ in U.S. securities, 80 percent of which are denominated in U.S. dollars and 20 percent of which are denominated in a foreign currency. Further, assume that the U.S. dollar appreciates 10 percent with respect to this foreign currency. From the U.S. perspective, the appreciation will have the effect of reducing the value of U.S. liabilities 2 percent (the 80 percent denominated in U.S. dollars is unaffected; the 20 percent denominated in the foreign currency decreases in value 10 percent; the total effect is a 2 percent reduction in value). From the foreign perspective, however, the value of foreign assets has increased 8 percent (the 20 percent denominated in foreign currency is unaffected; the 80 percent denominated in U.S. dollars increases in value 10 percent; the total effect is an 8 percent increase in value). cent respectively, bringing the corresponding market values of such holdings to $\$ 259$ billion and $\$ 458$ billion. Estimates of the repayment flows associated with foreign holdings of asset-backed securities are published on the TIC website. ${ }^{12}$ These repayment flows can be sizable: For 2005, they are estimated to have reduced foreign holdings of U.S. agency bonds by $\$ 48$ billion and such holdings of corporate bonds by $\$ 38$ billion. U.S. holdings of foreign asset-backed securities are still relatively small but have been increasing.

Unlike asset-backed securities, which gradually decline in value, zero-coupon securities gain value over time as they accumulate implicit interest payments. Again, these increases in value will not be captured by the monthly transactions system but will be measured by the annual surveys. Cross-border holdings of zero-coupon securities are much smaller than such holdings of asset-backed securities. According to the asset and liabilities surveys conducted in 2004, foreign investors held zero-coupon U.S. securities with a market value of $\$ 20$ billion and a face value at maturity of $\$ 30$ billion. The corresponding figures for U.S. investors' holdings of zerocoupon foreign securities were $\$ 10$ billion and $\$ 16$ billion respectively.

\section{Offshore Financial Centers}

An institution is considered to be resident in the country in which it is incorporated or otherwise legally created. In many cases, residency and the center of economic activity coincide. But when they differ, problems of data interpretation arise. For example, companies frequently create corporations and "special-purpose vehicles" (SPVs) in so-called offshore financial centers to take advantage of the tax or regulatory benefits that these countries offer. ${ }^{13}$ When these entities issue securities, the issues will be

12. Estimates of monthly asset-backed repayment flows since June 2002 are available at www.treas.gov/tic/absprin.html.

13. A special-purpose vehicle is a legal entity created in an offshore financial center (OFC) to engage in financial activities in a low-tax environment. An onshore corporation establishes an SPV in an offshore center to engage in a specific activity, such as the issuance of asset-backed securities. The onshore corporation may assign a set of assets to the offshore SPV (for example, a portfolio of mortgages, loans, or credit card receivables). The SPV then offers to investors a variety of securities based on the underlying assets. The SPV, and hence the onshore parent, benefit from the favorable tax treatment in the OFC. Financial institutions also use SPVs to take advantage of less-restrictive regulations on their activities. Banks, in particular, use them to raise Tier I capital in the lower tax environments of OFCs. And nonbank financial institutions create them to take advantage of more-liberal netting rules than those faced in home countries-rules that enable such institutions to reduce their capital requirements. 
attributed to the country of the offshore financial center rather than to the country of the onshore parent corporation, even though the onshore parent corporation may be understood to be the ultimate obligor. Further, some companies have reincorporated from their country of origin to offshore financial centers for tax purposes. Although the reincorporation probably has little or no effect on their locus of activity, securities issued by these companies will now be attributed to the country of reincorporation.

U.S. holdings of securities issued in offshore financial centers, especially those in the Caribbean, pose a challenge to measuring and interpreting U.S. investors' portfolios. Equity issued in offshore centers, in large part reflecting the equity of reincorporated multinationals and other entities controlled by onshore corporations, accounts for a growing percentage of the U.S. portfolio of foreign assets: In 1997, U.S. holdings of equity issued by Caribbean offshore financial centers (Bahamas, Bermuda, British Virgin Islands, Cayman Islands, Netherlands Antilles, and Panama) amounted to $\$ 48$ billion, or roughly 4 percent of all foreign equity held by U.S. investors. By the end of 2004, these amounts had grown to $\$ 277$ billion, or nearly 11 percent of all foreign equity held.

The growing share of these holdings in U.S. investors' foreign equity portfolios affects the degree to which their portfolios are exposed to exchange rate risk. An increase in the share of foreign equity in an investor's portfolio usually raises foreign currency exposure. Equity issued through offshore financial centers, however, is typically either dollar denominated or denominated in currencies pegged to the dollar, and so it carries a different exchange rate exposure. Although foreign equity still represents a fairly small share of the total equity portfolio held by U.S. investors, the share has grown in recent years, from about 9 percent in 1997 to about 14 percent in 2004. But the increase in foreign currency exposure of U.S. equity portfolios has been more modest, as more than 1 percentage point of that 5 percentage point increase has been attributable to the acquisition of equity issued in Caribbean offshore centers.

Holdings of long-term debt issued in offshore financial centers present a different challenge. Here U.S. holdings consist largely of debt securities issued through SPVs, especially those established in the Cayman Islands. Such holdings of Cayman Island debt by U.S. investors amounted to about 2 percent of U.S. investors' holdings of foreign bonds in 1997 but had grown to nearly 12 percent by 2004. Partly because of the growth of both asset-backed and conventional debt issued through offshore financial cen- ters and held by U.S. investors, the U.S.-dollardenominated share of foreign long-term debt has increased in recent years, from 60 percent in 1997 to 72 percent by the end of 2004 .

The increase in U.S. holdings of equity and debt issued by offshore centers raises questions about the interpretation of such securities in the U.S. portfolio. Although these securities fit the definition of foreign securities, U.S. investors may not regard them as such, as they trade in U.S. dollars on U.S. exchanges and are often issued by firms that conduct their market activity largely in the United States and otherwise behave like U.S. firms. Likewise, when foreign investors acquire such securities, they may consider them equivalent to U.S. securities.

On the U.S. liabilities side, the acquisition of U.S. securities by entities in offshore financial centersespecially those in the Caribbean-poses additional obstacles to interpreting cross-border financial activity. Such activity partly reflects the importance of these Caribbean countries as international financial centers, and purchases and sales recorded against these regions typically represent the first leg of a series of international transactions. It may also reflect the buying and selling of securities by the numerous investment funds that have been established in such offshore locations. Moreover, because many financial institutions have affiliated banking and nonbanking offices in these offshore locations, analyzing securities transactions through these centers can be difficult without knowing whether offsetting transactions are occurring through other parts of the financial accounts. For example, net financial outflows in the form of net sales of U.S. securities through financial centers may be offset by equally sizable net inflows reported in the TIC banking data from the same financial centers.

Caribbean financial centers are an increasingly important location for cross-border transactions in U.S. securities: Gross trading in long-term U.S. securities through these centers has grown from less than 10 percent of total cross-border trades in the first half of the 1990s to nearly 30 percent in the past five years. Net transactions through Caribbean financial centers can also be quite volatile, as they may record large foreign net purchases of long-term securities one month and large foreign net sales the next.

\section{Repurchase and Securities-Lending Agreements}

Repurchase agreements, or repos, are arrangements whereby the owner of a security sells it for cash and agrees to repurchase it at a future time (or under 
other specified conditions) at an agreed-upon price. Although some market participants engage in repo transactions to gain control of certain securities, repos are often structured as cash loans for traders who use the cash received in the repo transaction as a low-cost loan to fund their securities purchases, whereas the lenders receive the securities as collateral against borrower default. The securities typically used as collateral are U.S. Treasury securities and, to a lesser extent, U.S. government agency and corporate debt securities.

Securities-lending agreements are similar to repurchase agreements in that the owner transfers title of the securities to a borrower who agrees to return a like quantity of the same or similar securities at a future date or under other agreed-upon conditions. Again, the borrower provides collateral, but unlike in the case of repos, for which securities are used as collateral, the collateral for securities-lending agreements can be cash, other securities, or bank-issued letters of credit. Many market participants engage in securities-lending transactions to obtain securities needed to meet delivery obligations; for example, brokers may need to cover a failed trade, or investors may want to create a "short" position. ${ }^{14}$ Both equity and debt securities are involved in securities-lending arrangements.

Repurchase and securities-lending agreements pose a problem for the TIC system. Although both arrangements involve the outright sale of securities, the TIC system does not treat them as such. Instead, it treats them as collateralized loans, as the return of the same or similar securities at a set price is agreed upon in advance and thus the economic risk of holding the securities continues to reside with the securities lender (the economic owner) even while the lender does not own the securities. Repurchase and securities-lending agreements are not recorded as purchases or sales of securities in the monthly transactions data. Instead, funds loaned to or borrowed from foreigners under such agreements are reported on the TIC B forms. For the benchmark surveys, lenders (or their custodians) are instructed to report the securities as continuously held, and borrowers (or their custodians) are instructed not to count them as holdings.

As a result of treating securities-lending agreements as collateralized loans, the TIC system may

14. A short sale is the sale of a security not owned. Securities are borrowed-typically from a brokerage firm-and then sold in the hope that the price of the security will fall. If the price drops, the security can then be bought at the lower price and returned to the lender at a profit. Conversely, if the price of the security rises, a loss is incurred. report larger foreign ownership of U.S. securities than it would if these agreements were recorded as outright sales, since there is both an economic owner and a legal owner of the same security. Although TIC instructions specify that only the economic owner should be reported, TIC-reporting entities may lack sufficient information to follow these instructions properly. Further, the legal owner has the right to resell a borrowed security, and the subsequent buyer or the institution reporting on behalf of the buyer may have no knowledge that the security was originally borrowed. This situation can result in two different foreign residents being reported on a liabilities survey as holding the same U.S. security, or it can result in the same U.S. security being reported as having been purchased twice by foreign residents with no intervening sale.

\section{Comprehensiveness of the Data}

In general, the data on U.S. liabilities are considered to be reasonably comprehensive, as debt instruments tend to be issued by and bought or sold through large institutions that can be fairly readily identified and included in the data reporting network. U.S. foreign assets held by or through large U.S. institutions should also be well recorded. However, for smaller U.S. investors, directly purchasing foreign securities abroad without using the services of a large, U.S.resident institution is increasingly easy. Such acquisitions will not be captured in the U.S. recording system but will most likely be recorded as liabilities by the counterparty country's measurement system. Because all countries face this problem, cross-border assets are probably undercounted worldwide.

\section{Stock Swaps}

An additional problem is that the TIC S data fail to capture U.S. acquisitions of foreign stock and foreign acquisitions of U.S. stock that arise from stock swaps associated with corporate mergers or takeovers. When a foreign company acquires a U.S. company and the deal is financed in part through a stock swap, U.S. residents who held stock in the target company become holders of foreign equity. Likewise, if a U.S. company acquires a foreign company, a stock swap can increase foreign holdings of U.S. equity. Although missing from the TIC S data, stock swaps are reported in the BEA's quarterly balance of payments statistics, and monthly estimates of swaps 
based on these statistics are provided on the TIC website. ${ }^{15}$

Although merger activity has tapered off in recent years, stock swaps previously were an important source of financing such activity. For example, in 2000 , U.S. residents acquired $\$ 13$ billion in foreign equity through net purchases but $\$ 80$ billion through stock swaps associated with foreign acquisitions of U.S. companies.

\section{Adjustments to the Transactions Data}

We have raised a number of caveats that users should be aware of when using the TIC securities data. However, users can take some straightforward steps that will help them use the published data more effectively. Users can obtain more-comprehensive estimates of cross-border securities flows by incorporating the estimates described earlier for principal repayment flows of asset-backed securities and for stock swaps. Combining flows of short-term securities with the transactions data on long-term securities can also improve coverage. In addition, users should be aware of the problem of financial center transactions bias when attributing securities flows to individual countries. Because survey data on securities holdings are believed to be more accurate than the higher-frequency transactions data, combining the two sources can substantially improve one's understanding of both the magnitude and the country attribution of cross-border securities holdings. We explore these ideas in greater detail in the following sections.

\section{ESTIMATING POSITIONS BY COUNTRY BETWEEN SURVEYS}

Although the annual surveys give comprehensive measures of holdings by country at a point in time, analysts often wish to have a time series of holdings by country, as well as more-current measures of holdings. For short-term securities, the data from the TIC B forms provide reasonably comprehensive measures of current holdings. For long-term securities, however, estimates must be constructed.

This section describes the construction of monthly estimates of asset and liabilities positions that are

15. Data from Security Data Corporation on the financing of corporate mergers and takeovers are used to distribute the quarterly statistics of stock swaps by month. Monthly estimates from January 2000 through recent months are available at www.treas.gov/tic/ swapstk.html. consistent with the survey positions taken at annualor, as in the past, at less frequent-intervals. The procedure is based on that described in a recent Federal Reserve Bulletin article and extended in a related research paper by Thomas, Warnock, and Wongswan (2004), although the numerical computation procedure has been simplified from that presented in the paper. ${ }^{16}$

\section{Basic Position Estimate}

We begin with an illustration of the basic situation for total U.S. long-term securities held by foreigners (figure 5). In the figure, the dots show the actual survey values for total foreign holdings of U.S. longterm securities. Note that the length of time between surveys varies from one to five years. The black lines show "naive" position estimates obtained by summing monthly net transactions from the date of the previous survey. (As discussed above, we have reduced the naiveté of the estimates by adjusting the net transactions for principal repayment flows of asset-backed securities and for stock swaps.)

16. Refer to William L. Griever, Gary A. Lee, and Francis E. Warnock (2001), "The U.S. System for Measuring Cross-Border Investment in Securities: A Primer with a Discussion of Recent Developments," Federal Reserve Bulletin, vol. 87 (October), pp. 63350, www.federalreserve.gov/pubs/bulletin/2001/1001lead.pdf; and Charles P. Thomas, Francis E. Warnock, and Jon Wongswan, "The Performance of International Portfolios," International Finance Discussion Papers Series 2004-817 (Washington: Board of Governors of the Federal Reserve System, October), www.federalreserve.gov/pubs/ ifdp/2004/817/default.htm.

5. Foreign holdings of U.S. long-term securities: Comparison of survey values with monthly position estimates, 1984-2005

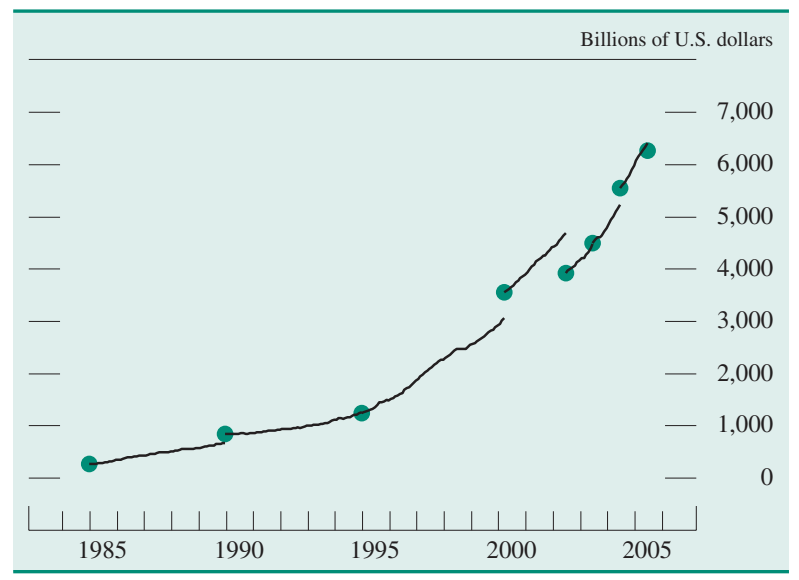

NoTE: Dots represent positions reported in liabilities surveys. Lines represent monthly position estimates obtained by adding net transactions to the position of the previous survey. 
The figure shows eight survey values. For the last seven of these, we can compare the survey result with the naive estimate made starting from the previous survey. In two years (2000 and 2002), a very substantial "gap" separates the estimate and the actual survey result, whereas in 1989 and 2004, a much smaller gap exists, and in 1994, 2003, and 2005, virtually no gap exists at all. (In 1984, of course, no gap is defined, as this year is the starting point for our analysis because of a lack of usable earlier data.)

\section{Adjustment for Valuation Change}

One way of improving the monthly position estimates is to include an estimate of the valuation change from one month to the next. Starting from the previous survey, one can apply the change in relevant securities price indexes to the previous position to obtain an estimate of the capital gain or loss from month to month. For foreign holdings of U.S. longterm securities, the composition of the security portfolio being held (for example, long-term U.S. Treasury bonds) is known, and obtaining an appropriate price index for evaluating changes in Treasury bond prices is fairly easy. In contrast, U.S. holdings of foreign securities comprise securities issued by many different countries, greatly compounding the valuation estimation problem. To estimate valuation changes for foreign securities, we use individual country equity or bond price indexes for most countries, taking into account the currency composition of U.S. holdings. ${ }^{17}$ However, in some cases-for example, for pricing the holdings of securities issued by offshore financial centers-the best estimate will result from using information on the holdings of individual foreign securities derived from the U.S. asset survey data to construct a customized index, as no published index currently available is appropriate.

We present estimated monthly positions obtained by adding net transactions to the previous survey benchmark, adjusting the results for valuation changes (figure 6). In general, the gaps between the estimated positions and the following benchmark survey are smaller than in figure 5, though the large gap in 2000 now switches sign: Adjusting for valuation changes during the stock market boom in the late

17. For holdings of bonds issued by most industrial countries, we use local currency bond indexes to estimate valuation changes. For debt issued by most emerging-market countries, we use J.P. Morgan's Emerging Markets Bond Index Plus (EMBI+) indexes, which track returns of debt denominated in external currencies. The EMBI+ indexes are appropriate because the majority of emerging-market debt held by U.S. investors is dollar denominated.
6. Foreign holdings of U.S. long-term securities: Comparison of survey values with monthly position estimates adjusted for valuation changes, 1984-2005

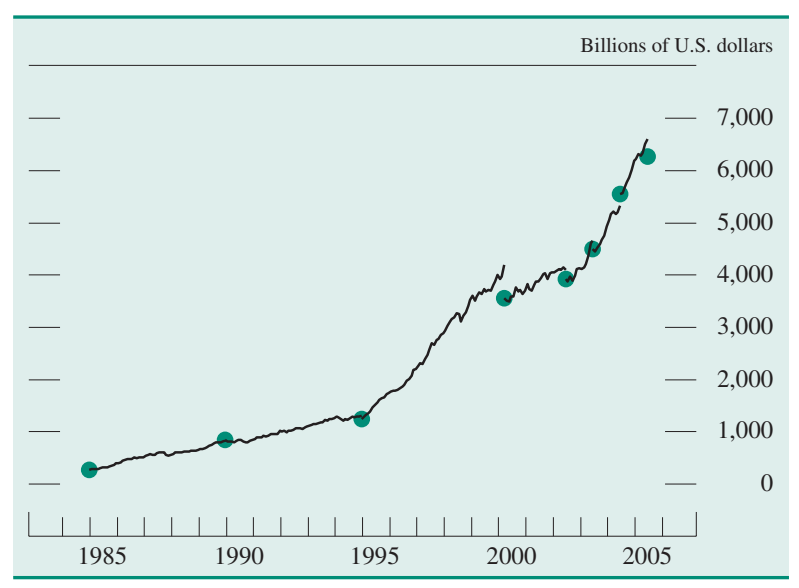

NOTE: Dots represent positions reported in liabilities surveys. Lines represent monthly position estimates obtained by adding net transactions to the position of the previous survey and by adjusting the result for valuation changes.

1990s now leads to an overestimate of actual foreign holdings of U.S. securities. We also note that the adjustment for valuation changes introduces a degree of high-frequency variability into the estimated positions.

\section{Distribution of Gap Error}

The survey gaps represent known information that can be used to estimate positions between surveys. Because we believe the surveys are more likely than the monthly position estimates to accurately measure securities positions, we assume that the sum of the net transactions, adjusted as described earlier, is in error by the amount of the gap. The gap represents errors and omissions in the monthly transactions data of current S-form reporters, as well as transactions conducted by entities that have not yet been identified as prospective reporters. In addition, the gap may be due to various measurement and approximation errors in constructing the prices used to calculate the valuation adjustment.

Of course, we lack knowledge of how the errors reflected in the overall gap error are distributed over time; we know only how large the gap is and that it accumulated over the period from the previous survey to the present. To proceed, we must make an assumption about the distribution of the gap over the intersurvey period. We assume, as did Thomas, Warnock, and Wongswan, that the gap is distributed in proportion to the volume of transactions in each 
7. Foreign holdings of U.S. long-term securities: Comparison of survey values with monthly position estimates adjusted for valuation changes and gap error, 1984-2005

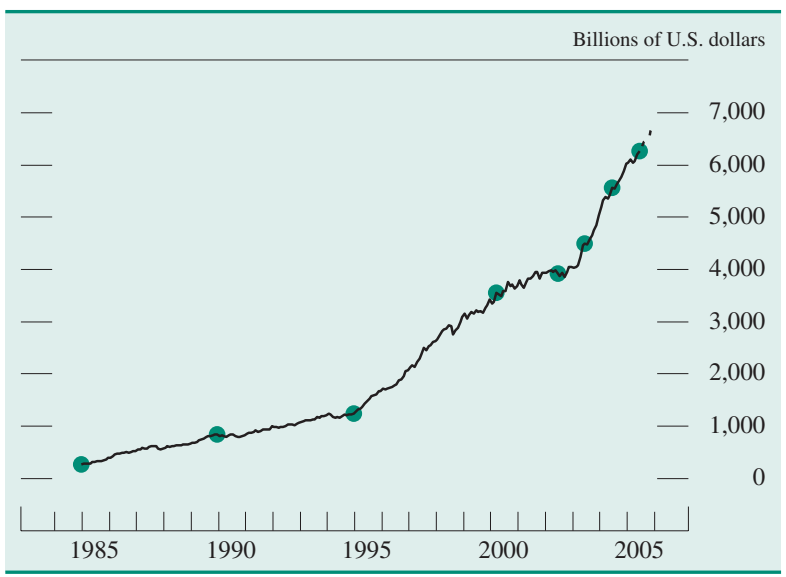

NoTE: Dots represent positions reported in liabilities surveys. Lines represent monthly position estimates obtained by adding net transactions to the position of the previous survey and by adjusting the result for valuation changes. Gap error is distributed in proportion to the volume of monthly transactions; the distribution allows for the effect of price changes. Dashed line indicates forecast.

month over the period and that the distribution allows for the effect of price changes.

Applying this procedure generates an estimated monthly path for total foreign holdings of U.S. longterm securities (figure 7). Note that the gaps have been eliminated, as the line passes through all the dots, representing survey values. The line also appears to exhibit attenuated versions of the line variations in figure 6 , illustrating that the estimation procedure preserves the variability introduced by valuation changes.

Note also that a dotted line extends beyond the last survey date. The extension represents an estimate of the future position based on observed transactions and prices and on a forecast of the survey gap. As discussed in the next section, the estimates for many countries seem to exhibit gaps that tend to be either consistently positive or consistently negative. Accordingly, we forecast the next future survey gap by using the simple average of the previous two actual gaps, scaled by nominal position and by time. ${ }^{18}$

18. We first scale the gaps by nominal position (the actual survey value) to convert the nominal magnitude of the raw gaps to a unitsfree measure, allowing comparisons across countries and across surveys. We then scale the gaps by time (the number of months between surveys), recognizing that errors in measuring the true position are additive from month to month. Applying this second normalization significantly reduces the magnitude of the gaps in the early part of the sample.

\section{Estimated Positions Adjusted for Transactions Bias}

We present the same illustration (showing estimated monthly positions and forecast gaps) for U.S. securities held by investors in the United Kingdom and in euro-area countries (figure 8). Note that the gaps for the United Kingdom are consistently large and positive, an indication that the transactions-based monthly estimates consistently overstate the actual positions eventually reported in the surveys. In contrast, the gaps for the euro area are generally substantial and negative, a sign that the monthly estimates consistently understate the actual positions.

The explanation for this result is the transactions bias inherent in the monthly TIC S data reported for the United Kingdom: London is a major financial

8. Holdings of U.S. long-term securities by the United Kingdom and by euro-area countries: Comparison of survey values with adjusted monthly position estimates, 1994-2005

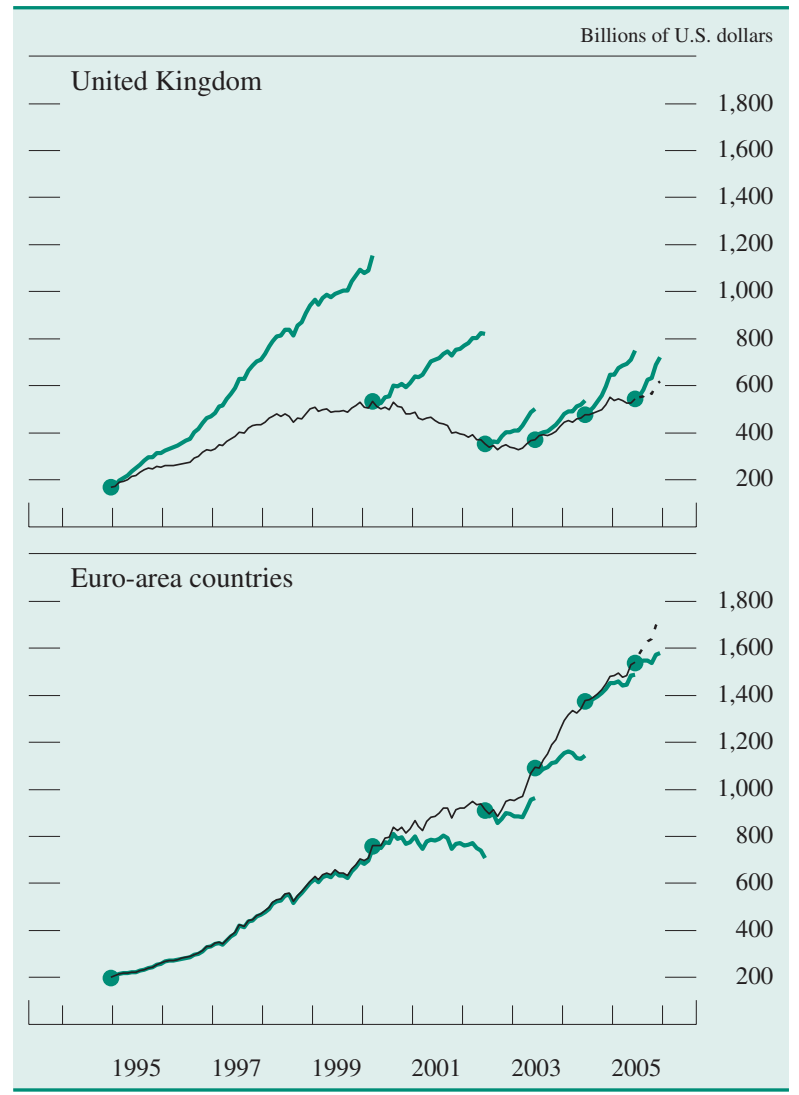

Note: Dots represent positions reported in liabilities surveys. In each panel, the line connecting all the dots represents monthly position estimates adjusted for valuation changes and gap error as described in the note to figure 7; the lines extending separately from the dots represent monthly position estimates adjusted only for valuation changes. Dashed lines indicate forecasts. 
center, and financial intermediaries in London often buy U.S. securities on behalf of customers in other countries, many of whom are in the euro area. This pattern, which emerges quite clearly in the data, has significant implications for forecasting the positions of individual countries. As shown by the dotted black line in the first panel of figure 8, the projected U.K. position rises by about $\$ 90$ billion by year-end 2005, reflecting the typical historical pattern, but this increase is less than what we would estimate on the basis of flows and valuation adjustments alone (indicated by the line extending from the nearest dot). In contrast, the projection for the euro area indicates an increase in holdings of about $\$ 200$ billion, about $\$ 130$ billion more than would be implied by flows and valuation adjustments.

\section{Applications of Position Estimates}

Besides providing between-survey and more-recent estimates of both foreign holdings of U.S. securities and U.S. holdings of foreign securities-by country and with an adjustment for transactions bias-our estimates can also help identify potential problems with the TIC data system and improve reporting. As a new survey becomes available, we can compare our estimates, constructed forward from the previous survey, with the reported values in the new survey. If the estimates are considerably different from what the survey indicates, the difference suggests that errors exist in the transactions data, the valuation changes applied over the intersurvey period, the survey results, or some combination of these factors.

The experience of the December 2003 survey of U.S. holdings of foreign securities illustrates how this approach can identify missed reporting and improve the TIC reporting system. Estimating forward from the December 2001 survey generates a value for U.S. holdings of about $\$ 650$ billion in foreign long-term debt as of December 2003 — slightly higher than the roughly $\$ 600$ billion measured at the end of December 2001-which resulted from small reported net sales of foreign debt over the two-year period plus positive valuation changes (figure 9). That estimate was significantly lower than the figure reported in the December 2003 survey, which valued U.S. holdings of foreign long-term debt securities at nearly $\$ 870$ billion, about $\$ 220$ billion more than expected. An in-depth investigation of the securities reported in the survey showed that U.S. investors held a sizable amount of newly issued foreign debt. These findings suggested that an area of missed reporting most likely involved new issues of foreign securities in the
9. U.S. holdings of foreign long-term debt securities: Comparison of survey values with adjusted monthly position estimates, 2001-04

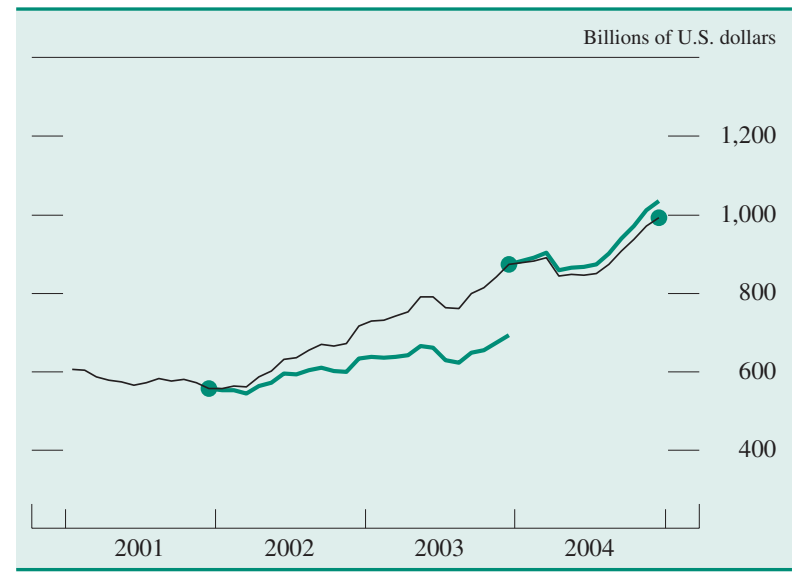

NoTE: Dots represent positions reported in asset surveys. The line connecting all the dots represents monthly position estimates adjusted for valuation changes and gap error as described in the note to figure 7; the lines extending separately from the dots represent monthly position estimates adjusted only for valuation changes.

United States, and indeed, further investigation of $\mathrm{S}$-form reporters indicated reporting errors in this area. Although most respondents on the $\mathrm{S}$ form have not revised their reports for omissions in 2002 and 2003, S-form reporting appears to capture new issues of foreign bonds more completely for the data beginning in 2004. The results from the December 2004 survey have been encouraging: Measured U.S. holdings of foreign debt came in much closer to the estimated positions.

\section{COMPARING U.S. LIABILITIES ESTIMATES WITH CPIS ASSET POSITIONS}

Although our estimated between-survey positions of foreign holders of U.S. securities are corrected for transactions bias, they still suffer from the custodial bias present in the liabilities surveys. However, we can perhaps gain a better understanding of the true owners of U.S. securities - and of the possible holders of U.S. bearer bonds - by comparing our liabilities positions with holdings of U.S. securities as reported by other countries in the Coordinated Portfolio Investment Surveys (CPIS), which are conducted annually under the auspices of the International Monetary Fund (IMF). ${ }^{19}$ The CPIS asset surveys represent a commitment to collect and pub-

19. Because the CPIS asset surveys are conducted annually as of December 31, whereas the liabilities surveys are conducted annually as of June 30, we compare the CPIS measures with our betweensurvey estimates of holdings as of December 31. 
lish comprehensive data on foreign portfolio security holdings. Approximately seventy countries participate in the CPIS, measuring and reporting, by country, their domestic investors' portfolio holdings of equity, long-term debt, and short-term debt; the U.S. asset survey is the United States' contribution to this cross-country effort. ${ }^{20}$

Because the individual country asset surveys in the CPIS are expected to be accurate in terms of country attribution, their estimates of holdings of U.S. securities will be free of custodial bias. The absence of such bias should permit the comparison of each CPIS country's reported holdings of U.S. equity and longterm debt with our reported liabilities data. But some complications attend this comparison. First, the amounts of U.S. securities reported in the CPIS surveys include only nonreserve holdings, and thus they will not be comparable to our liabilities measures, which include sizable foreign official holdings. ${ }^{21} \mathrm{Sec}-$ ond, the CPIS surveys will also suffer from the problem that asset surveys generally are not as comprehensive in terms of their coverage of holders within a country as are liabilities surveys. Finally, some countries that are major foreign holders of U.S. securities, as identified in the U.S. liabilities surveys, do not participate in the CPIS. ${ }^{22}$

\section{Foreign Holdings of U.S. Long-Term Debt Securities}

Because official reserves are rarely held in the form of equity, the omission of reserve holdings from the CPIS surveys is more problematic for comparing holdings of U.S. debt securities than for comparing holdings of U.S. equities. Nonreserve holdings of U.S. long-term debt securities as measured by CPISreporting countries were $\$ 1.2$ trillion at year-end 2001 and had grown to more than $\$ 2$ trillion by year-end 2004 (table 3). Although we can distinguish official holdings from private holdings in the U.S. liabilities surveys (and in our year-end estimates based on these survey values), this distinction is confidential at the country level. Because we want to

20. The IMF collects and publishes these data on its website at www.imf.org/external/np/sta/pi/cpis.htm (select "CPIS Data"). Also available is descriptive information about each country's survey technique (select "CPIS Metadata"), which can be used to help judge the quality and comprehensiveness of the country surveys.

21. The tables in the IMF's Survey of Geographical Distribution of Securities Held as Foreign Exchange Reserves (SEFER) report aggregate data on total U.S. securities held as reserves by SEFER-reporting countries; the data are not reported by country.

22. Notably, the CPIS excludes mainland China, Taiwan, and most Middle Eastern oil-exporting countries.
3. Foreign holdings of U.S. long-term debt securities: Estimated foreign assets, estimated U.S. liabilities, and the difference between the estimates, for CPIS-reporting countries, year-end 2001-04

Billions of dollars

\begin{tabular}{|c|c|c|c|c|}
\hline \multirow{2}{*}{ Item } & \multicolumn{4}{|c|}{ Market value of holdings } \\
\hline & 2001 & 2002 & 2003 & 2004 \\
\hline Foreign assets & 1,695 & 1,948 & 2,420 & 3,094 \\
\hline CPIS surveys (nonreserves) & 1,165 & 1,369 & 1,710 & 2,010 \\
\hline Reserves $^{1}$............. & 530 & 580 & 710 & 1,084 \\
\hline U.S. liabilities ${ }^{2}$ & 1,899 & 2,164 & 2,532 & 3,131 \\
\hline Difference (liabilities less assets) & 204 & 216 & 112 & 37 \\
\hline
\end{tabular}

Note: Coordinated Portfolio Investment Surveys (CPIS), also known as CPIS surveys, are conducted annually as of December 31, whereas U.S. liabilities surveys are conducted annually as of June 30. Liabilities estimates represent between-survey estimates of holdings as of December 31.

1. Estimated for each CPIS-reporting country from aggregate reported reserve holdings of U.S. long-term debt securities in dollars as reported by the International Monetary Fund (IMF). For a description of the estimation procedure, refer to text note 23 .

2. Nonreserve and reserve asset holdings as well as a prorated share of unallocated bearer bonds.

SOURCE: For CPIS surveys, IMF, www.imf.org/external/np/sta/pi/cpis.htm; for reserves, IMF data (refer to text note 23); for U.S. liabilities, Treasury International Capital reporting system, www.treas.gov/tic/fpis.html.

compare, country by country, holdings of U.S. securities as reported in the U.S. liabilities surveys with those reported in the CPIS, we impute an estimate of reserves in dollars for each CPIS-reporting country, using aggregate reported reserve holdings of U.S. long-term debt securities in dollars as reported by the IMF. ${ }^{23}$

23. The IMF-published reserve holdings consist of data on total reserve holdings in the form of U.S. long-term securities as reported in the IMF SEFER survey, data on total reserves less gold as of the various year-end dates for each country as reported in International Financial Statistics, and data on the estimated fraction of reserves held in dollars as recorded in the IMF database known as COFER (Currency Composition of Foreign Exchange Reserves). We start by using IMF COFER data to construct the fraction of reserves held in dollars. For industrial countries, the COFER data indicate that roughly 76 percent of reserves were dollar denominated at year-end 2001, 72 percent at year-end 2002, 73 percent at year-end 2003, and 72 percent at year-end 2004. We assume that all industrial countries held these fractions of their nongold reserves in dollars. For all other countries, the COFER data indicate that, of the reserves for which currency was identified, 70 percent were dollar denominated at yearend 2001, 65 percent at year-end 2002, 62 percent at year-end 2003, and 61 percent at year-end 2004. We assume that all non-industrial countries held these fractions of their nongold reserves in dollars. These calculations give an estimate of roughly $\$ 1.5$ trillion in aggregate dollar reserves as of the end of 2003.

Because not all of these estimated dollar reserves are held in long-term U.S. debt securities, we then prorate the estimated holdings of reserves in dollars per country by the proportion of SEFERreported U.S. long-term debt securities in each period to estimated aggregate dollar reserves. For more information on the IMF data, refer to the SEFER webpage, www.imf.org/external/np/sta/pi/sec.htm; International Monetary Fund (2006), International Financial Statistics, February; and the COFER webpage, www.imf.org/external/np/ sta/cofer/eng/index.htm. 
Adding an estimate of dollar reserves held in the form of U.S. long-term debt securities increases the CPIS-based estimates considerably. These estimates are still somewhat lower than those based on the liabilities surveys, although the gap has narrowed in recent years. The estimates based on CPIS asset holdings plus estimated reserve holdings of U.S. longterm debt securities give figures of $\$ 1.7$ trillion in such securities as of the end of 2001 and $\$ 3.1$ trillion as of the end of 2004. In comparison, total holdings of U.S. securities as reported in the U.S. liabilities surveys for the set of CPIS-reporting countries (including a prorated share of the unallocated bearer bonds identified in the liabilities surveys) are $\$ 1.9$ trillion at the end of 2001 and $\$ 3.1$ trillion at the end of 2004. Overall, the difference between the two estimates of aggregate foreign holdings of U.S. securities is small enough to suggest that the country-bycountry estimates are also reasonably accurate, and indeed, we find for many countries that the CPISplus-reserve estimates are quite close to our liabilities figures. However, as would be expected, the two measures also diverge for many countries: Our reported holdings are considerably larger than the CPIS-based estimates in several instances, and they are smaller in others.

We illustrate the differences between the two estimates for 2004 (figure 10). Our liabilities estimates for 2004 are notably larger than the CPIS-based estimates for Belgium, the Cayman Islands, and Luxembourg, and they are larger by somewhat smaller amounts for Switzerland and Germany, an indication that custodial bias may overstate these countries' combined holdings of U.S. long-term debt securities by about $\$ 660$ billion. ${ }^{24}$

In contrast, our liabilities estimates for U.S. longterm debt securities are smaller than the CPIS-based estimates for Japan (by more than $\$ 120$ billion in 2004) and for a number of other countries, most notably the Channel Islands, the United Kingdom, Bermuda, Hong Kong, Italy, and France. Taken together, the CPIS data suggest that our liabilities estimates understate investment in U.S. long-term debt securities in this group of countries by more than $\$ 480$ billion in 2004 . These results indicate that at least some of the custodial bias overstatement most evident for Belgium, Luxembourg, and the Cayman Islands likely reflects ultimate beneficial ownership by investors in the countries for which our estimates are understated, although a portion may also reflect ownership by investors in countries not included in the CPIS surveys.

\section{Foreign Holdings of U.S. Equities}

As noted earlier, the omission of reserve holdings in the CPIS surveys has little effect on our comparison of liabilities estimates of foreign holdings of U.S.

24. An additional problem for comparing the estimates for the Cayman Islands is that the coverage of the CPIS survey for the islands is incomplete, as it is based on assets as reported by banks only and thus excludes securities held by the large number of mutual funds that operate in the Cayman Islands.

10. Differences between U.S. liabilities estimates and CPIS-based asset estimates of foreign holdings of U.S. long-term debt securities, for selected CPIS-reporting countries, December 2004

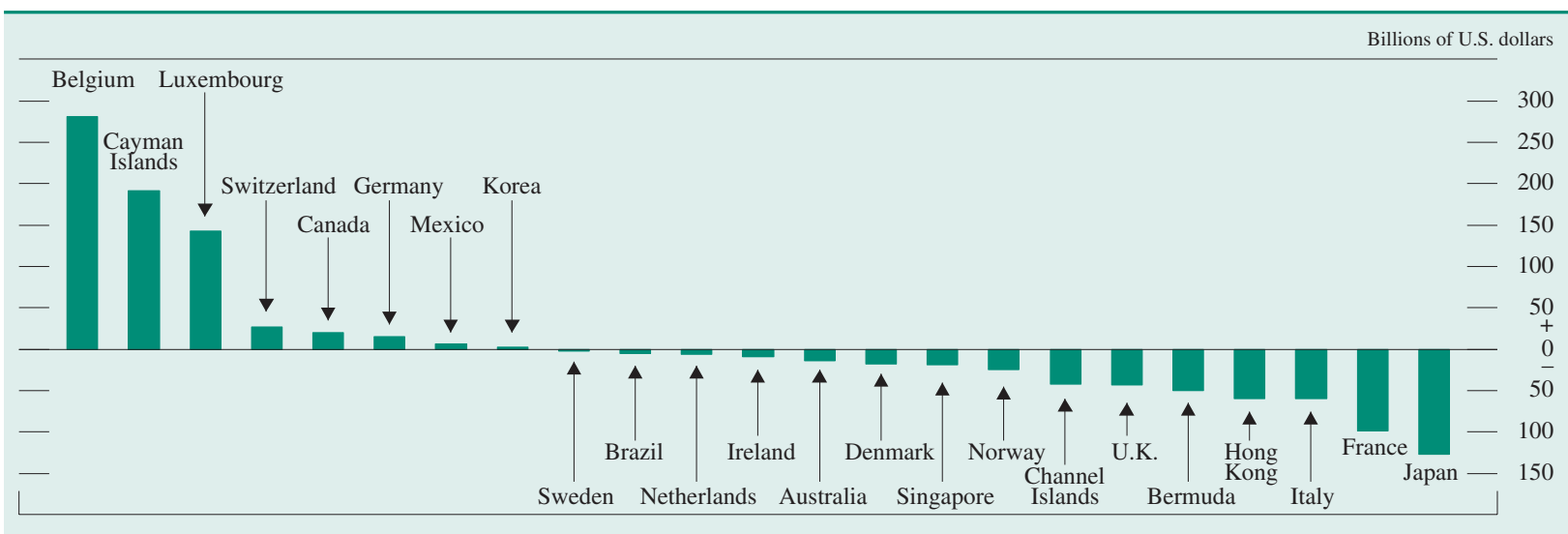

NotE: Refer to notes to table 3. Difference for each country is calculated by subtracting a CPIS-based asset estimate from a U.S. liabilities estimate. CPIS-based asset estimate consists of nonreserve holdings as reported in the

CPIS surveys and reserve holdings as estimated from data published by the International Monetary Fund. 
4. Foreign holdings of U.S. equities: Reported foreign assets, estimated U.S. liabilities, and the difference between these measures, for CPIS-reporting countries, year-end 2001-04

Billions of dollars

\begin{tabular}{c|rr|r|r|}
\hline \multirow{2}{*}{ Item } & \multicolumn{4}{|c}{ Market value of holdings } \\
\cline { 2 - 6 } & 2001 & 2002 & 2003 & 2004 \\
\hline Foreign assets (CPIS surveys) ${ }^{1} \ldots \ldots \ldots$ & 997 & 902 & 1,267 & 1,470 \\
U.S. liabilities $2 \ldots \ldots \ldots \ldots \ldots \ldots \ldots$ & 1,390 & 1,237 & 1,712 & 1,966 \\
Difference (liabilities less assets) $\ldots . .$. & 393 & 335 & 445 & 497 \\
\hline
\end{tabular}

NotE: Refer to general note to table 3 .

1. Nonreserve holdings only.

2. Nonreserve and reserve holdings. For estimated holdings by all foreign official institutions, refer to text note 25 .

SOURCE: For foreign assets, International Monetary Fund, www.imf.org/external/np/sta/pi/cpis.htm; for U.S. liabilities, Treasury International Capital reporting system, www.treas.gov/tic/fpis.html.

equities with CPIS-reported holdings. ${ }^{25}$ As of yearend 2001, CPIS-reporting countries held in aggregate a little more than $\$ 1$ trillion in U.S. equity; this amount had increased to almost $\$ 1.5$ trillion by yearend 2004 (table 4). Comparison with our liabilities surveys suggests a more significant undercount in the CPIS surveys for equities than for long-term debt, as our liabilities-based estimates indicate holdings of U.S. equity by CPIS-reporting countries of $\$ 1.4$ trillion in 2001 and \$2.0 trillion in 2004 (although in percentage terms that gap has also narrowed in recent years). Consequently, we find more countries for which our liabilities-based estimates are larger than the CPIS-reported holdings, and we find fewer

25. Our liabilities estimates show that foreign official holdings of U.S. equity were $\$ 94$ billion in 2001, $\$ 87$ billion in 2002, $\$ 125$ billion in 2003, and \$162 billion in 2004. countries for which our estimates are smaller (figure 11). Nonetheless, for several of the countries for which our liabilities estimates for equity are largerthe Cayman Islands, Switzerland, Germany, and Belgium - our estimates for long-term debt were also larger, providing further indications of custodial bias in our liabilities estimates for these countries.

\section{Foreign Holdings of All U.S. Long-Term Securities}

Overall, the comparison of estimates from the U.S. liabilities surveys with values reported in the CPIS surveys supports our interpretation that the liabilities surveys overstate holdings in several large custodial centers, especially Belgium, Luxembourg, and the Cayman Islands. Correspondingly, the holdings reported in the U.S. liabilities surveys of several other European as well as some Asian countries are smaller than the CPIS-based estimates, although some of the custodial center holdings as well as some bearer bonds no doubt represent holdings of countries that have not yet participated in the CPIS surveys. In general, our analysis provides support for the comparability of both the CPIS and the U.S. liabilities surveys, and it suggests that both types of surveys are capturing comparable securities holdings.

\section{SUMMARY AND CONCLUSION}

In recent years, U.S. cross-border securities activity has grown dramatically. As such activity attracts greater attention, it is increasingly important to have

11. Differences between U.S. liabilities estimates and CPIS asset reports of foreign holdings of U.S. equities, for selected CPIS-reporting countries, December 2004

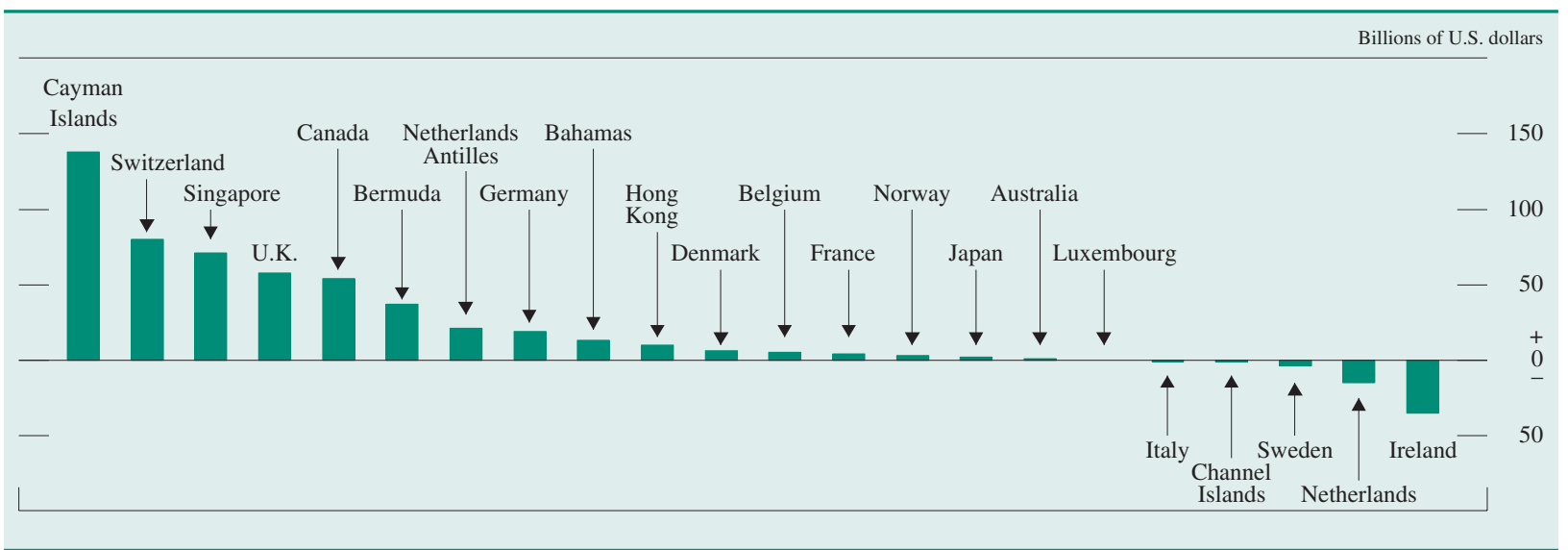

NotE: Refer to notes to table 4 . Difference for each country is calculated by subtracting a CPIS-reported asset level from a U.S. liabilities estimate. 
a data collection system that both accurately tracks these positions and flows and is well understood by data users.

To properly interpret the data on cross-border portfolio activity, users should understand the strengths and weaknesses of the system that produces the data. In this article, we outline a number of factors that influence the interpretation of the data collected in the TIC system, focusing especially on the data on cross-border securities. We note ways in which the data on monthly transactions in long-term securities may provide an incomplete or misleading picture of cross-border securities flows, and we describe several adjustments that can improve the usefulness and comprehensiveness of the published data.

We also discuss a procedure that combines information collected in the most comprehensive part of the TIC system, the annual surveys, with morecurrent but less comprehensive data on monthly secu- rities transactions to provide more-timely estimates of cross-border securities holdings by country. This approach improves our ability to correct estimated holdings for the bias inherent in the monthly transactions data and to adjust holdings for valuation changes.

Although our survey-based estimates of foreign holdings of U.S. securities are considered to be comprehensive in their coverage, their country attribution is imperfect because of the custodial bias in the data. We illustrate how information on holdings of U.S. securities as reported in other countries' asset surveys can help data users to better interpret the country attribution of data obtained from U.S. liabilities surveys. As cross-border financial activity continues to evolve and foreign data reporting systems continue to improve, such complementary sources of information may become increasingly beneficial in analyzing U.S. cross-border securities data. 